University of Nebraska - Lincoln

DigitalCommons@University of Nebraska - Lincoln

Faculty Publications from the Harold W. Manter Laboratory of Parasitology

8-1-2006

\title{
Aspidoderidae from North America, with the Description of a New Species of Aspidodera (Nematoda: Heterakoidea)
}

\author{
F. Agustin Jimenez-Ruiz \\ Southern Illinois University, Carbondale, fruiz@unlserve.unl.edu \\ Scott Lyell Gardner \\ University of Nebraska - Lincoln, slg@unl.edu \\ Andrea S. Varela-Stokes \\ Mississippi State University, stokes@cvm.msstate.edu
}

Follow this and additional works at: https://digitalcommons.unl.edu/parasitologyfacpubs

Part of the Parasitology Commons

Jimenez-Ruiz, F. Agustin; Gardner, Scott Lyell; and Varela-Stokes, Andrea S., "Aspidoderidae from North America, with the Description of a New Species of Aspidodera (Nematoda: Heterakoidea)" (2006). Faculty Publications from the Harold W. Manter Laboratory of Parasitology. 39.

https://digitalcommons.unl.edu/parasitologyfacpubs/39

This Article is brought to you for free and open access by the Parasitology, Harold W. Manter Laboratory of at DigitalCommons@University of Nebraska - Lincoln. It has been accepted for inclusion in Faculty Publications from the Harold W. Manter Laboratory of Parasitology by an authorized administrator of DigitalCommons@University of Nebraska - Lincoln. 


\title{
ASPIDODERIDAE FROM NORTH AMERICA, WITH THE DESCRIPTION OF A NEW SPECIES OF ASPIDODERA (NEMATODA: HETERAKOIDEA)
}

\author{
F. Agustín Jiménez-Ruiz ${ }^{\star}$, Scott L. Gardner*, and Andrea S. Varela-Stokes $†$ \\ The Harold W. Manter Laboratory of Parasitology, University of Nebraska State Museum, Lincoln, Nebraska 68588-0514. e-mail: \\ fruiz@unlserve.unl.edu
}

\begin{abstract}
Aspidodera sogandaresi n. sp. (Heterakoidea: Aspidoderidae) from Dasypus novemcinctus Linnaeus, 1758 is herein described. This nematode occurs in armadillos from as far south as the canal zone of Panama, north through central Mexico, and into the southern United States. Previously identified as Aspidodera fasciata (Schneider, 1866), this new species has blunt projections on the lips and lateral expansions at the distal tips of the spicules, whereas A. fasciata has conspicuous digitiform projections on the lips, and a terminal round expansion at the tips of the spicules. Other species of the family present in North America include Aspidodera binansata Railliet and Henry, 1913; Aspidodera vazi Proença, 1937; and Lauroia trinidadensis Cameron, 1939.
\end{abstract}

The Aspidoderidae, Skrjabin and Schikhobalova, 1947 (Ascaridida: Heterakoidea) currently includes 16 species divided among 4 genera. The worms occur in the cecum and large intestine of mammals with southern Nearctic and general Neotropical distributions. The known host range for species in the family includes xenarthrans, didelphiomorphs, and hystricognath and sigmodontine rodents.

Five species of the family have been recorded from armadillos north of the Isthmus of Panama, including Mexico and the United States (Chandler, 1946; Caballero, 1955; Flores-Barroeta, 1956); in opossums from Guatemala, Mexico, Panama, and the United States (Chandler, 1932; Foster, 1939; Caballero and Cerecero, 1944; Aldes, 1995); and in hystricognath and geomyid rodents from the United States, Mexico (Lamothe-Argumedo et al., 1997), and Central America. Species recorded include Aspidodera fasciata (Schneider, 1866) Railliet and Henry, 1913; Aspidodera raillieti Travassos, 1913; Lauroia dasypi Caballero, 1955; Lauroia intermedia Flores-Barroeta, 1956; and Paraspidodera uncinata (Rudolphi, 1819) Travassos, 1914.

Species assignable to Aspidodera Railliet and Henry, 1912 are diagnosed by the distinctive structure of the "hood" on the anterior-most end of the nematode, which has recurrent grooves covered by a cuticle; these structures are known as the cordons (Inglis, 1957). Characters used in combination to identify these nemas to the level of the species include the cordons, the shape and length of the spicules, the shape of the spinneret, and the number of caudal papillae (Santos et al., 1990). Herein, we describe a new species of Aspidodera and present 3 new records of Aspidodera in Central and North America.

\section{MATERIALS AND METHODS}

Thirteen nine-banded (or long-nosed) armadillos, Dasypus novemcinctus Linnaeus, 1758, were collected from 2001 through 2003 in Mexico and the United States (Fig. 1). Armadillos were obtained from local hunters and as road-kills in Morelos, Nayarit, Oaxaca, Veracruz, Florida, and Texas. Some specimens were captured alive and killed with chloroform in the field. Additional specimens collected from armadillos in the United States and Panama were borrowed from the United States National Parasite Collection (USNPC).

For this study, the large intestine was opened, washed in water, and aliquots were examined with a dissecting microscope. Nematodes found

Received 13 September 2005; revised 21 November 2005; accepted 6 January 2006

* School of Biological Sciences, University of Nebraska, Lincoln, Nebraska 68588-0514.

$\dagger$ Department of Infectious Diseases, College of Veterinary Science, University of Georgia, Athens, Georgia 30602. were washed in water and immediately placed in $9 \%$ physiological saline prior to killing. Separate aliquots or samples of individual parasites were killed either in glacial acetic acid, $70 \%$ ethanol, or $10 \%$ formalin. Specimens were stored in either $70 \%$ ethanol or $10 \%$ formalin. Some specimens collected alive were washed in $9 \%$ saline solution and preserved in $95 \%$ ethanol for later study using molecular methods. Note that these specimens are deposited in the Harold W. Manter Laboratory of Parasitology (HWML) and will be available for DNA sequencing, and can be requested by referencing the HWML number. For examination via light microscopy, specimens fixed as above were cleared in lactophenol, mounted on a slide under a No. 1 coverslip, and studied with a light microscope. Specimens were identified using published descriptions and by direct comparison with type specimens. Specimens prepared for scanning electron microscopy (SEM) were treated with osmium-thiocarbohydrazide-osmium-thiocarbohydrazide-osmium (OTOTO), dehydrated in $100 \%$ ethanol, dried to a nonliquid state by critical-point drying using $\mathrm{CO}_{2}$, attached to an SEM stub, and sputter coated with gold palladium.

Specimens examined were borrowed from and deposited into the following collections: Colección Helmintologica do Instituto Oswaldo Cruz (CHIOC), Rio de Janeiro, Brazil; Colección Nacional de Helmintos (CNHE), Mexico City, Mexico; Collection of Parasitology of the School of Veterinary Medicine of the University of Hokkaido (CPSVM), Sapporo, Japan; and the USNPC, Beltsville, Maryland. Species used for comparisons included Aspidodera vazi Proença, 1937 (CHIOC 9641, 14086, 18354); Aspidodera binansata Railliet \& Henry, 1913 (CHIOC 8260, 9637, 9639, 9643, 18351, and USNPC 58363); A. fasciata (CHIOC 4119, 11190; USNPC 8550, 26644, 59968; CPSVM 2950); Aspidodera scoleciformis (Schneider, 1851) Railliet and Henry, 1912 (CHIOC 10, 5681, 5809, 8387, 9668, 11408, 14551, 15073, 15257, 18355, 19494, 19628, 20046, 34557, 34568); and L. intermedia (CNHE 2460).

Specimens were measured using an ocular micrometer or Sigmascan Pro Image Analyzer (Albinger et al., 1995) attached to a Zeiss ultraphot microscope. Measurements are given in micrometers. For each character studied, the range is given first, followed by sample mean, and coefficient of variation (as a percent value; Sokal and Rohlf, 1995) in parentheses. Drawings were made with a Wild microscope equipped with a drawing tube. Specimens imaged with SEM were exposed to a beam of $15 \mathrm{KV}$ on both Hitachi field S-2460N and S-3000 scanning electron microscopes.

\section{RESULTS}

From the 11 armadillos infected, we identified 4 species of aspidoderid nematodes including 1 of Lauroia Proença, 1938 and 3 of Aspidodera. One of the species of Aspidodera was undescribed. Species found in $D$. novemcinctus, localities, and museum accession numbers are listed in Table I. This is the first record of a species of Aspidodera from armadillos in Mexico.

\section{Redescription}

\section{Lauroia trinidadensis Cameron, 1939}

Diagnosis: Nemas with slender bodies, sharp tail, red when alive. Cephalic plates with continuous cordons, velum around 


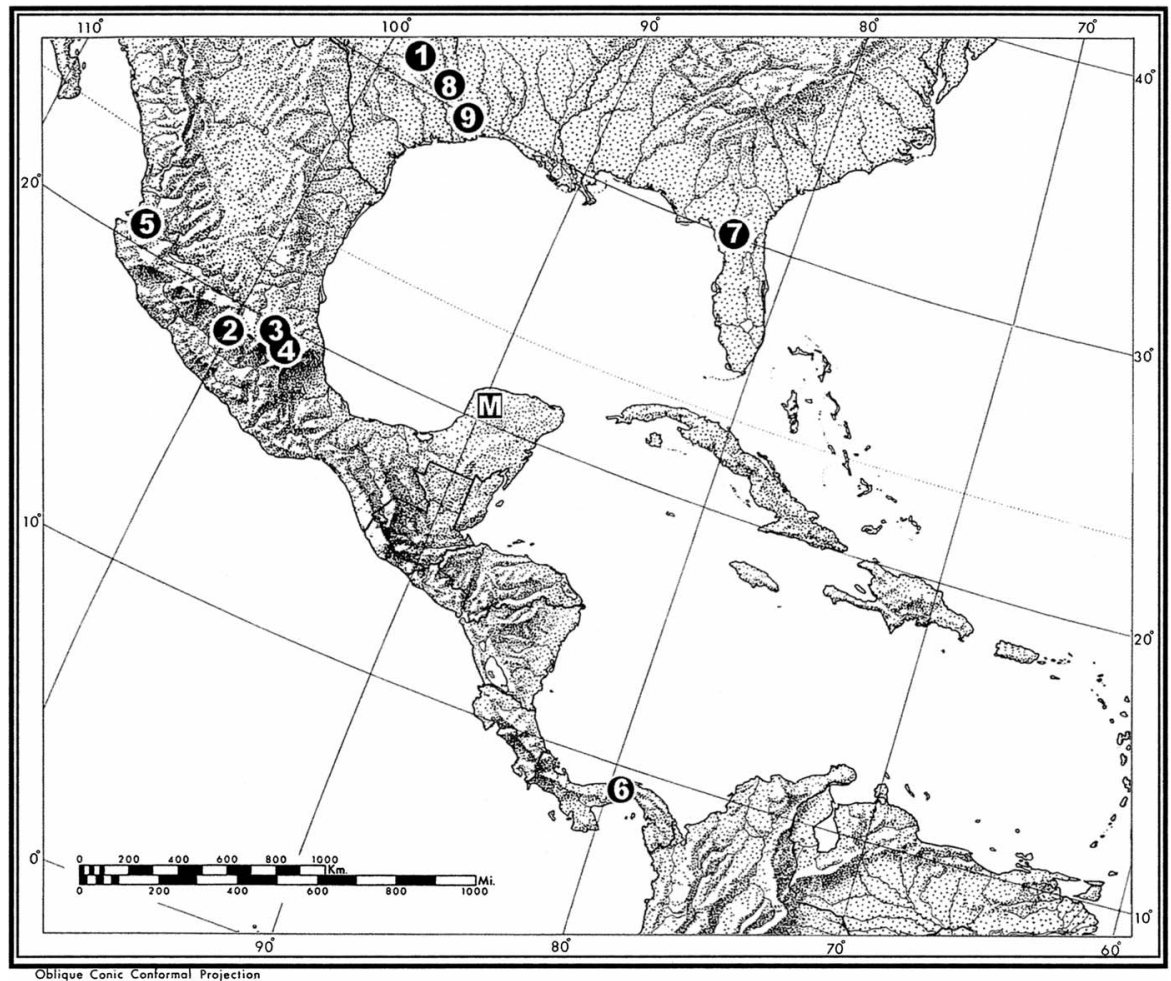

Figure 1. Collecting localities for A. sogandaresi n. sp. in North and Central America. (1) El Pedregal, 18 miles north by road (U.S. 281), Lampasas, Texas; (2) Teacalco; (3) Isla Limón Presa, Miguel Alemán; (4) Piscifactoria Temazcal; (5) Carretera Tepic-Aguamilpa Km 8; (6) Canal Zone; (7) Alachua County; (8) College Station; (9) Houston; M) Mérida.

lateral and posterior margins of plate; interlabium developed as a cuticular ridge at base of plates. Lateral longitudinal fields developed into thick and round lateral alae. Precloacal sucker without rim. Gubernaculum absent.

\section{Taxonomic summary}

Host: Dasypus novemcinctus Linnaeus, 1758.

Localities: Mexico: Oaxaca, Isla Limón Presa Miguel Alemán, $18^{\circ} 17^{\prime} 07^{\prime \prime} \mathrm{N}, 96^{\circ} 34^{\prime} 55^{\prime \prime} \mathrm{W}, 49 \mathrm{~m}$ elevation (22 May 2001; prevalence 50\% 2/2). Piscifactoria Temazcal, $18^{\circ} 15^{\prime} 30^{\prime \prime} \mathrm{N}$, $96^{\circ} 25^{\prime} 14^{\prime \prime} \mathrm{W}, 62 \mathrm{~m}$ elevation (24 May 2001). Yucatán, Mérida, $20^{\circ} 58^{\prime} 52^{\prime \prime} \mathrm{N}, 8^{\circ} 36^{\prime} 36^{\prime \prime} \mathrm{W}$ (19 November 2001) (Fig. 1).

Specimens deposited: Vouchers CMNPA2005-0025, CNHE5363 through CNHE5366, HWML48193 through HWML48195, HWML48244, CHIOC35432, USNPC97135, and USNPC97136.

Habitat: Attached to mucosa and in lumen of large intestine.

\section{Aspidodera binansata Railliet and Henry, 1913}

Diagnosis: Two recurrent branches of cordons on surface of dorsal plate, latero-ventral plates bearing 1 anterior and 1 posterior loop. Interlabium arising as a projection between plates. Lateral longitudinal fields developed in thin lateral alae. Spinneret whip-shaped.

\section{Taxonomic summary}

Host: Dasypus novemcinctus Linnaeus, 1758.

Localities: Mexico: Yucatán, Mérida, 20 $58^{\prime} 52^{\prime \prime} \mathrm{N}, 89^{\circ} 36^{\prime} 36^{\prime \prime} \mathrm{W}$
(19 November 2001). Panama: Canal Zone, 0857'41"N, $79^{\circ} 33^{\prime} 54^{\prime \prime} \mathrm{W}$ (Fig. 1).

Specimens deposited: Vouchers CNHE5367 and USNPC58363.

Habitat: In lumen of large intestine.

\section{Aspidodera vazi Proença, 1937}

Diagnosis: Very elongated hood, posterior loops of hood widely separated on each plate. Interlabium arising as projection between plates. Lateral longitudinal fields simple or with lateral alae. Spinneret whip-shaped.

\section{Taxonomic summary}

Host: Dasypus novemcinctus Linnaeus, 1758.

Localities: Mexico: Nayarit, Carretera Tepic-Aguamilpa Km $8,21^{\circ} 32^{\prime} 16^{\prime \prime} \mathrm{N}, 104^{\circ} 52^{\prime} 25^{\prime \prime} \mathrm{W}, 79 \mathrm{~m}$ elevation (16 June 2003). Oaxaca, Isla Limón Presa Miguel Alemán, 18¹7'07"N, $96^{\circ} 34^{\prime} 55^{\prime \prime} \mathrm{W}, 49 \mathrm{~m}$ elevation (22 May 2001; prevalence 50\% 2/ 2). Piscifactoria Temazcal, $18^{\circ} 15^{\prime} 30^{\prime \prime} \mathrm{N}, 96^{\circ} 25^{\prime} 14^{\prime \prime} \mathrm{W}, 62 \mathrm{~m}$ elevation (24 May 2001) (Fig. 1).

Specimens deposited: Vouchers CNHE5358, HWML48191, HWML48192, and USNPC97134.

Habitat: In lumen of large intestine.

\section{Description}

Aspidodera sogandaresi n. sp. (Figs. 2-6)

Diagnosis (358 worms collected from 8 localities in North America [Table I]; 21 additional specimens borrowed from 
TABLE I. Collection data for aspidoderid nematodes from the nine-banded armadillo (Dasypus novemcinctus Linnaeus, 1758) across Central and North America.

\begin{tabular}{|c|c|c|c|}
\hline Locality & Georeference & Species & Collection number \\
\hline Km 8, carretera Tepic-Aguamilpa, & $21^{\circ} 32^{\prime} 16^{\prime \prime} \mathrm{N}$ & Aspidodera sogandaresi & HWML48189 \\
\hline Teacalco, Morelos & $\begin{array}{l}18^{\circ} 37^{\prime} 12^{\prime \prime} \mathrm{N} \\
99^{\circ} 27^{\prime} 20^{\prime \prime} \mathrm{W}\end{array}$ & Aspidodera sogandaresi & $\begin{array}{l}\text { HWML48184, CHIOC } 35429, \\
\text { CMNPA2005-0023, CNHE5359 }\end{array}$ \\
\hline \multirow[t]{2}{*}{ Piscilfactoría Temazcal, Oaxaca } & $\begin{array}{l}18^{\circ} 15^{\prime} 30^{\prime \prime} \mathrm{N} \\
96^{\circ} 25^{\prime} 14^{\prime \prime} \mathrm{W}(62 \mathrm{~m})\end{array}$ & A. sogandaresi & $\begin{array}{l}\text { HWML48190, CNHE5362, } \\
\text { CHIOC } 35431\end{array}$ \\
\hline & & Lauroia trinidadensis & CNHE5365 \\
\hline \multirow[t]{3}{*}{ Isla Limón, Oaxaca } & $\begin{array}{l}18^{\circ} 17^{\prime} 07^{\prime \prime} \mathrm{N} \\
96^{\circ} 34^{\prime} 55^{\prime \prime} \mathrm{W}\end{array}$ & A. sogandaresi & $\begin{array}{l}\text { HWML48185-7, CNHE5360, } \\
\text { USNPC97133 }\end{array}$ \\
\hline & & A. vazi & HWML48191, USNPC97134 \\
\hline & & L. trinidadensis & $\begin{array}{l}\text { HWML48193-5, HWML48244, } \\
\text { CHIOC35432, CMNPA2005-0025, } \\
\text { CNHE5363-4, USNPC97135-36 }\end{array}$ \\
\hline Canal Zone & $08^{\circ} 57^{\prime} 41^{\prime \prime} \mathrm{N}$ & A. sogandaresi & USNPC58605 \\
\hline & $79^{\circ} 33^{\prime} 54^{\prime \prime} \mathrm{W}$ & A. binansata & USNPC58363 \\
\hline \multicolumn{4}{|l|}{ United States } \\
\hline $\begin{array}{l}\text { El Pedregal, } 18 \text { miles north of Lam- } \\
\text { pasas, Texas on U.S. } 281\end{array}$ & $\begin{array}{l}31^{\circ} 19^{\prime} 34^{\prime \prime} \mathrm{N} \\
98^{\circ} 09^{\prime} 33^{\prime \prime} \mathrm{W}(311 \mathrm{~m})\end{array}$ & A. sogandaresi & $\begin{array}{l}\text { HWML48179,* HWML48180, } \dagger \\
\text { HWML48181-3, HWML48243, } \\
\text { CHIOC35430, CMNPA2005-0024, } \\
\text { CNHE5361, USNPC97132 }\end{array}$ \\
\hline College Station, Texas & $\begin{array}{l}30^{\circ} 35^{\prime} 59^{\prime \prime} \mathrm{N} \\
96^{\circ} 18^{\prime} 42^{\prime \prime} \mathrm{W}\end{array}$ & A. sogandaresi & USNPC27135 \\
\hline Alachua County, Florida & $\begin{array}{l}29^{\circ} 40^{\prime} \mathrm{N} \\
82^{\circ} 20^{\prime} \mathrm{W}\end{array}$ & A. sogandaresi & HWML48188 \\
\hline
\end{tabular}

* Holotype.

$\dagger$ Allotype.

USNPC): Nemas with slender bodies, sharp tail, white when alive. Cephalic cap or hood with anastomosing cordons, 6 anteriad and 6 posteriad loops; interlabium well developed (Fig. 2a, b). Lips simple with blunt projections laterally. Interlocking structures between latero-ventrals formed by blunt projection on both sinistro-ventral and dextro-ventral lips (Fig. 2a). Dorsal lip with 1 papilla on each side; latero-ventral lips with 1 papillae and amphid on dorsal side and circular medial papilla (Fig. 2b). Inner face of dorsal lip with 2 pairs of sockets (Fig. 2b). Lateral fields not forming lateral alae (Fig. 3a).

Males (based on measurements of 29 specimens unless otherwise indicated): Body length 4,400-7,009, 5,855 (10.6\%); width at midbody 160-337, 268 (14.3\%) (Fig. 3a). Cephalic hood 191-264, 221 (9.3\%) long; 112-161, 138 (10\%) wide. Nerve ring and excretory pore located 390-548, $455(\mathrm{n}=25$, $9.4 \%)$ and 552-775, $669(\mathrm{n}=27,9.46 \%)$, respectively, from anterior end. Stoma length 33-58, $44(\mathrm{n}=28,14.8 \%)$. Length of esophagus including bulb 1,052-1,502, 1,313 (8.5\%). Pharynx length and width $43-88,64(\mathrm{n}=28,13.3 \%)$ by $33-56,44$ $(\mathrm{n}=28,13.5 \%)$. Corpus of esophagus 891-1,327, 1,086 $(10.6 \%)$ long. Width of esophagus at level of nerve ring 50$78,61(\mathrm{n}=28,10.1 \%)$. Bulb of esophagus pyriform 167-229, $190(\mathrm{n}=28,7.3 \%)$ long by $148-209,167(\mathrm{n}=28,8 \%)$ at maximum width. Length of left spicule 267-372, $331(\mathrm{n}=25$,
$7.2 \%)$; width at calomus 16-26, $22(\mathrm{n}=25,11.1 \%)$. Length of right spicule $226-363,320(\mathrm{n}=25,10.2 \%)$; width at calomus 16-26, 21 ( $\mathrm{n}=24,12.9 \%)$. Gubernaculum 101-148, 118 $(\mathrm{n}=25,7.8 \%)$ long by $14-27,21(\mathrm{n}=22,14.2 \%)$ wide (Fig. $3 \mathrm{~b}, \mathrm{c})$. Rim of sucker $66-95,75(9.2 \%)$ in diameter.

With 23-29 pairs of caudal sessile papillae distributed in fields anterior, lateral, and posterior to cloaca. Anterior or precloacal papillae consisting of 3 subventral and 1 lateral pairs, 1 single papilla flanked by 2 papillae on posterior part of rim. Lateral or adcloacal papillae consisting of 3-5 pairs, 1 papilla each flanking cloacal opening, 2 or 4 pairs sublateral to cloaca. Papillae distributed posterior to cloaca (postcloacal) consisting of 10-12 subventral and 5-9 lateral pairs (Fig. 3c).

Tail length 268-393, $311(9.1 \%)$ with needle-shaped spinneret $25-46,36(\mathrm{n}=28,14.9 \%)$ gradually tapering to a sharp point (Figs. 3b, 5a).

Females (based on measurements of 29 individuals, unless otherwise indicated): Body length 4,711-6,886, 5,601 (10.3\%); width at level of vulva 219-385, 297 (19.4\%). Nerve ring and excretory pore $361-523,457(\mathrm{n}=26,10.2 \%)$ and $549-757$, $648(\mathrm{n}=28,9.14 \%)$, respectively, from anterior end (Fig. 4). Cephalic hood 213-312, $259(\mathrm{n}=28,10.9 \%)$ long by $114-$ 258, $163(\mathrm{n}=28,17.7 \%)$ wide. Stoma $31-64,51(\mathrm{n}=27$, $16.5 \%$ ). Total length of esophagus including bulb 1,038-1,504, 

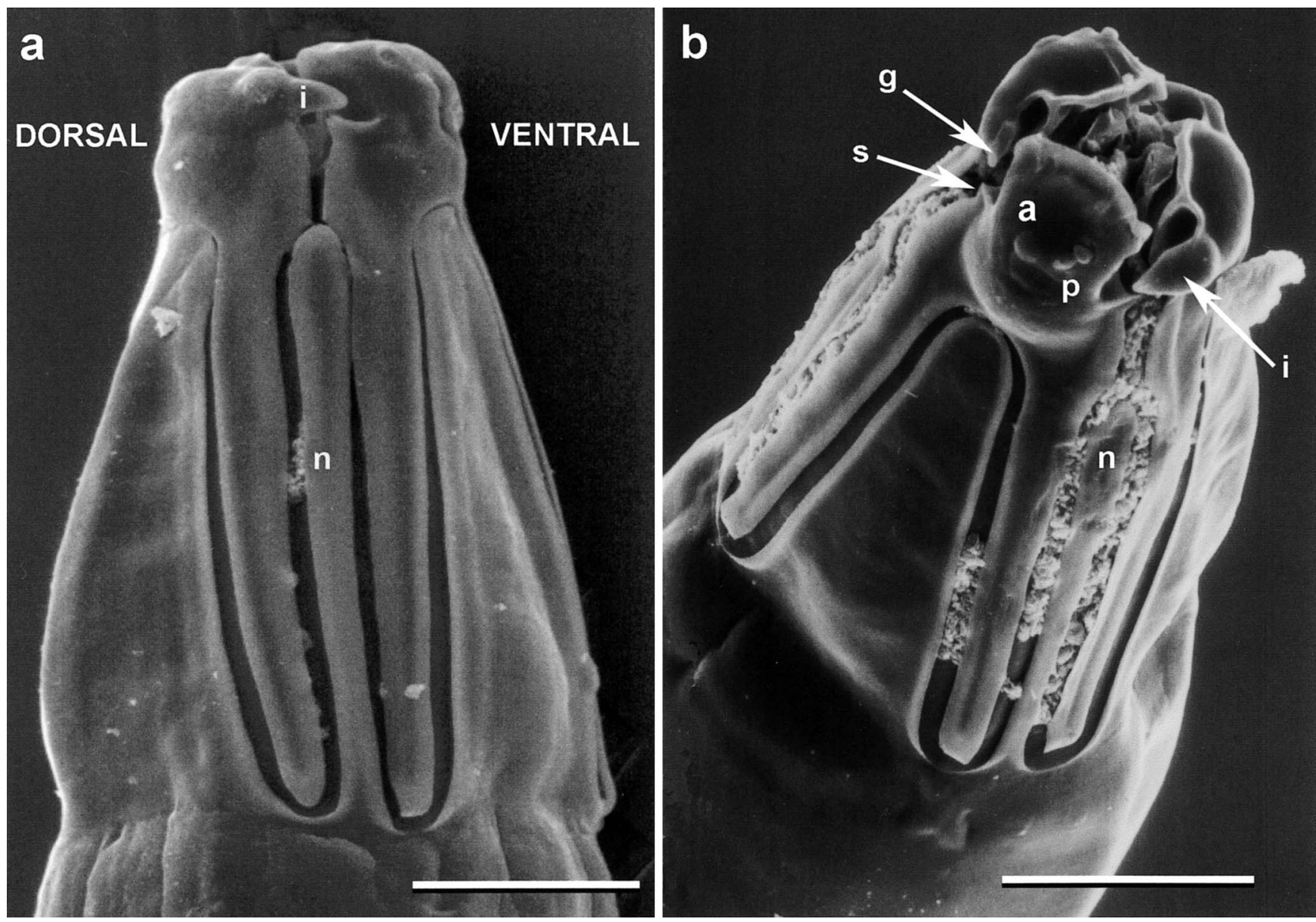

Figure 2. Hood of A. sogandaresi n. sp. (a) Detail of the right side female showing interlabium, "n"; cordons, and digitiform projection from the dorsal lip, "i." (b) Sinistroventral lip of male showing details of amphid "a"; 2 lateral papillae "p," the digitiform projection of the dextroventral lip, "g," and digitiform projection of the sinistroventral lip, "s." Scale bar $=50 \mu \mathrm{m}$.

$1,276(\mathrm{n}=26,9.0 \%)$. Pharynx 50-79, $64(\mathrm{n}=27,12.2 \%)$ long by $34-62,49(\mathrm{n}=27,14.7 \%)$ wide. Corpus length $925-1,310$, $1,071(\mathrm{n}=26,10.5 \%)$ by $41-94,63(\mathrm{n}=26,19.9 \%)$ wide. Bulb of esophagus $158-221,193(\mathrm{n}=28,8.4 \%)$ long by $123-$ 238, 168 ( $\mathrm{n}=27,16.2 \%)$ wide (Fig. 4). Vulva located 1,811$2,807,2,265(\mathrm{n}=24,13.0 \%)$ from anterior end (Fig. 4). Uteri containing embryonated eggs $60-92,71(\mathrm{n}=508,9.0 \%)$ by 40-70, 50 ( $\mathrm{n}=508,12.9 \%)$. Tail 319-554, $418(11.9 \%)$.

\section{Taxonomic summary}

Symbiotype: Dasypus novemcinctus Linnaeus, 1758, Museum of Southwestern Biology (MSB 145728).

Type locality: El Pedregal, 18 miles north by road (U.S. 281) from Lampasas, Texas, $31^{\circ} 19^{\prime} 34^{\prime \prime} \mathrm{N}, 98^{\circ} 09^{\prime} 33^{\prime \prime} \mathrm{W}$; elevation 311 $\mathrm{m}$ (see map in Fig. 1).

Prevalence in type locality: 100\% (3/3).

Date of collection of type specimens: 24 July 2001.

Other localities: Mexico: Morelos, Teacalco, 18 $37^{\prime} 12^{\prime \prime} \mathrm{N}$, $99^{\circ} 27^{\prime} 20^{\prime \prime} \mathrm{W}$ (22 May 2001; prevalence 100\%, 1/2). Oaxaca, Isla Limón Presa Miguel Alemán, $18^{\circ} 17^{\prime} 07^{\prime \prime} \mathrm{N}, 96^{\circ} 34^{\prime} 55^{\prime \prime} \mathrm{W}, 49$ $m$ elevation (22 May 2001; prevalence 50\% 2/2). Piscifactoria Temazcal, $18^{\circ} 15^{\prime} 30^{\prime \prime} \mathrm{N}, 96^{\circ} 25^{\prime} 14^{\prime \prime} \mathrm{W}, 62 \mathrm{~m}$ elevation (24 May 2001). Nayarit, Carretera Tepic-Aguamilpa Km 8, $21^{\circ} 32^{\prime} 16^{\prime \prime} \mathrm{N}$, $104^{\circ} 52^{\prime} 25^{\prime \prime} \mathrm{W}, 79 \mathrm{~m}$ elevation (16 June 2003). Panama: Canal Zone, $08^{\circ} 57^{\prime} 41^{\prime \prime} \mathrm{N}, 79^{\circ} 33^{\prime} 54^{\prime \prime} \mathrm{W}$. United States, Florida, Alachua County, $29^{\circ} 40^{\prime} \mathrm{N}, 82^{\circ} 20^{\prime} \mathrm{W}$; Texas, College Station, $30^{\circ} 35^{\prime} 39^{\prime \prime} \mathrm{N}$; Texas, Houston, $96^{\circ} 18^{\prime} 42^{\prime \prime} \mathrm{W}$ (Fig. 1).

Specimens deposited: Holotype, male HWML48179. Allotype, female HWML48180; paratypes HWML48181 through HWML48190, HWML48243, HWML48244, CNHE5359 through CNHE5362, CHIOC35429 through CHIOC35431, CMNPA 2005-0023, CMNPA 2005-0024, USNPC97132, and USNPC97133. Vouchers USNPC27135 and USNPC58605.

Habitat: Attached to mucosa and in lumen of large intestine.

Etymology: The species is named after Dr. Franklin Sogandares-Bernal, our good friend, H. W. Baldwin Ward Medalist, and pioneer in the taxonomy and systematics of parasites from Latin American vertebrates.

\section{Remarks}

Aspidodera sogandaresi is unique in having a wide expansion at the tip of the spicules (Fig. 5a), blunt projections on the lips (Fig. 6a), and lateral fields without conspicuous lateral alae. Aspidodera sogandaresi is different from A. scoleciformis, Aspidodera ansirupta Proença, 1937, and A. binansata in the 

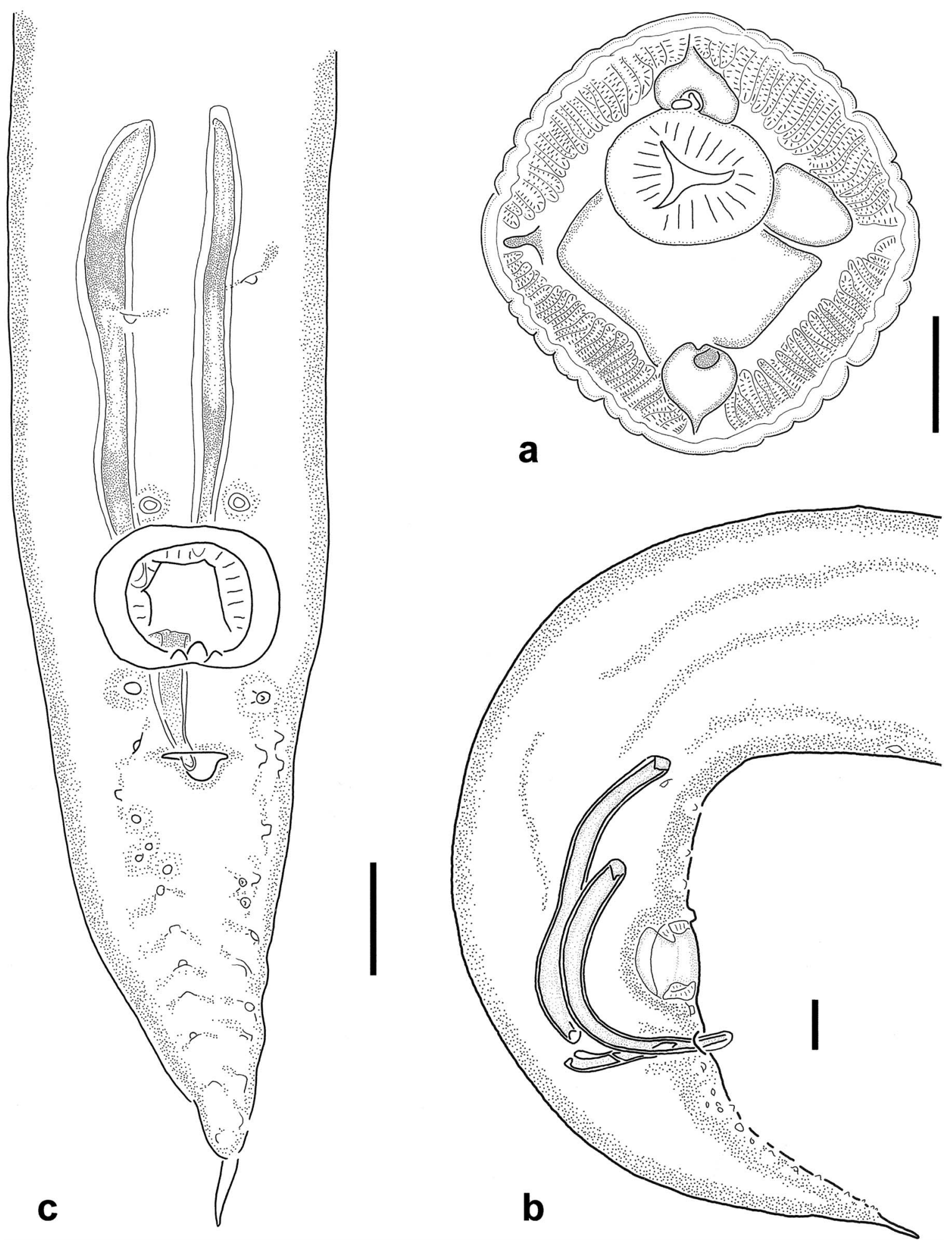

Figure 3. Details of the body of males of A. sogandaresi n. sp. (a) Cross-section showing smooth cuticle. (b) Detail of caudal end in lateral view. (c) Ventral view of caudal end showing genital papillae. Scale bar $=50 \mu \mathrm{m}$.

structure of the cordons and in the digitiform projections of the lips. Additionally, the cephalic hood in A. sogandaresi is larger than that in A. scoleciformis and A. ansirupta, and has a shorter tail than both $A$. scoleciformis and A. binansata. It is also dif- ferent from Aspidodera lacombae Vicente, 1964 in the size of the spicules and shape of the cordons.

Aspidodera sogandaresi has a shorter hood and shorter spicules as well as a needle-shaped spinneret in contrast with the 


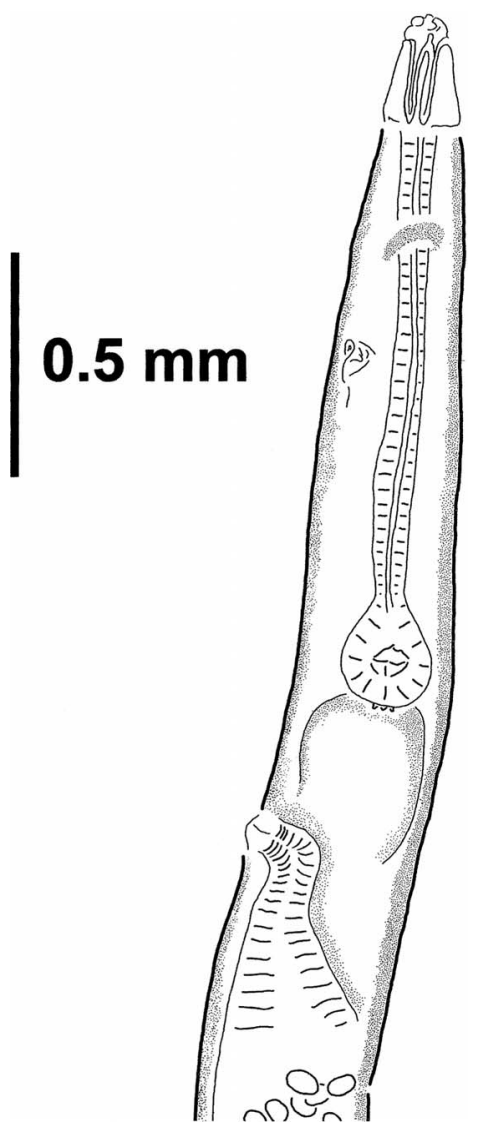

FIGURE 4. Anterior half of a female of Aspidodera sogandaresi $\mathrm{n}$. sp. showing the relative distances of nerve ring, excretory pore, and vulva to the anterior end.

long hood, long spicules, and whip-shaped spinneret of $A$. vazi. Also, there is a long digitiform projection arising from the dextroventral lip of A. sogandaresi ("g" on Fig. 6a) relative to the homologous structures of $A$. vazi ("g" on Fig. 6c). The species most similar to A. sogandaresi is A. fasciata. Similarities include grooves on the hood, shape of spinneret, and size of body. However, A. sogandaresi can be separated from A. fasciata by the more blunt and simpler digitiform projections on the lips (Fig. 6a), a tail tapering gradually to a point of the spinneret, and spicules with an expansion at the tip (Fig. 5a).

\section{DISCUSSION}

Chandler (1946) reported A. fasciata in armadillos near Houston, Texas, and determined that his material differed from A. fasciata from South America by being smaller; however, he did not consider these differences sufficient to warrant a description of these specimens as a new species. Additional specimens of $A$. sogandaresi were also collected from a nine-banded armadillo by Emmet Price on 2 April 1926, from the vicinity of College Station, Texas (USNPC27135); later, these specimens were identified by E. A. Chapin as A. fasciata. Comparison of these worms with our samples and with specimens of A. fasciata from South America (USNPC17957 and USNPC59968) allowed us to identify the blunt projections on the lips of A. sogandaresi (Fig. 6a) in contrast to the heavily serrated lips of A. fasciata (Fig. 6b). Figure 6 a, b shows that
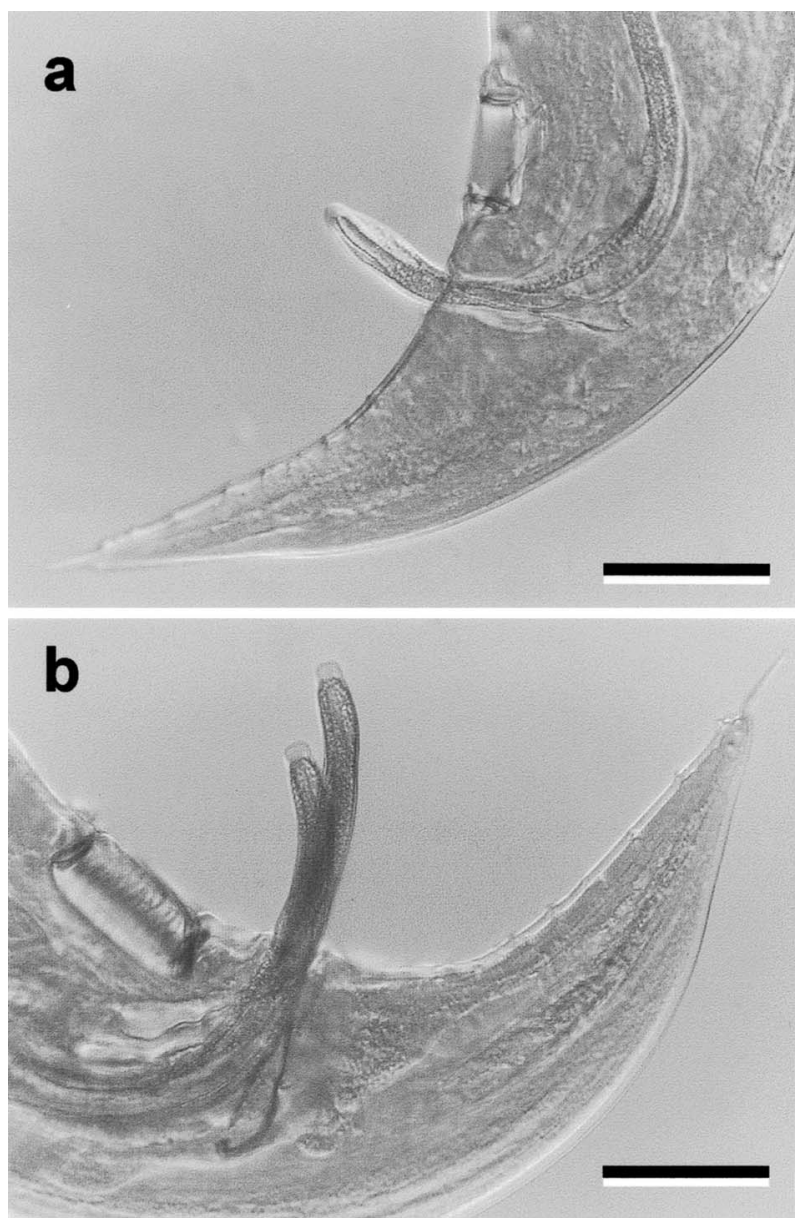

Figure 5. Comparison of caudal end and tip of spicules of 2 species of Aspidodera in lateral view. (a) A. sogandaresi n. sp. (b) A. fasciata. Scale bar $=100 \mu \mathrm{m}$.

the apparent simple interlocking lip system of A. sogandaresi is also evident on the sockets of the inner part of the dorsal lips. Figure 6 a clearly shows 2 pairs of sockets on the inner part of the dorsal lip that complements the simple projections arising from the lateroventral lips. In contrast, the homologous sockets on the dorsal lip of A. fasciata (Fig. 6b) are apparently more complex, matching the heavily serrated projections arising from the latero-ventral lips.

The number of caudal papillae was used by Santos et al. (1990) to distinguish among species in the Aspidoderidae. However, it appears that the number of papillae is highly variable, as there is variation in the number of papillae even among worms found in the same individual host. Because of the high variability of this character within and among species, we do not recommend its use for identification of species of Aspidodera.

Finally, lateral alae are absent in A. sogandaresi; nevertheless, some specimens show a flat lateral field associated with the hypodermal cord as shown in cross-section (Fig. 3a). A. vazi may show a similar pattern in the lateral alae, in that Navone (1986) showed that lateral alae were present in some but not all of the individuals she examined in Argentina. It appears that lateral alae may be a polymorphic character in $A$. vazi.

Lauroia trinidadensis Caballero 1955 and L. dasypi Flores- 

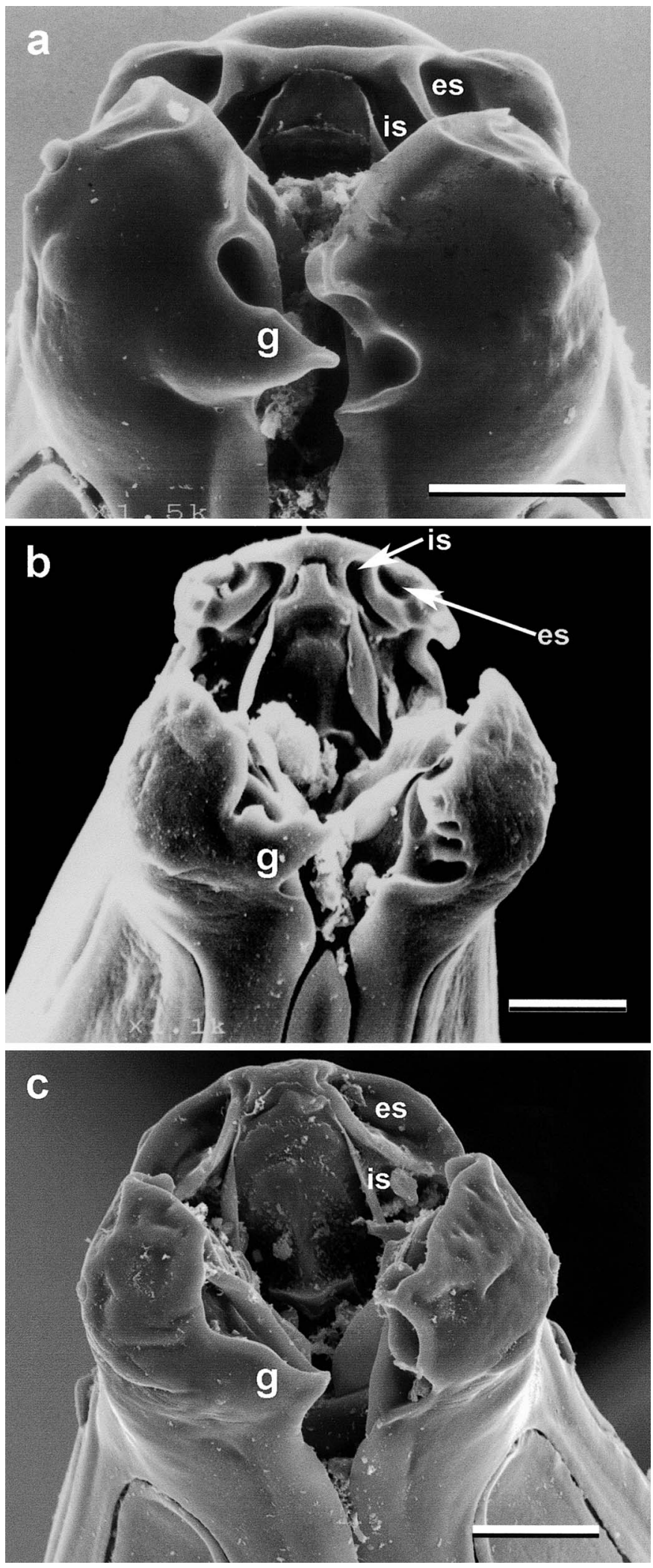

FIGURE 6. Comparison of the stoma and labial structures of 3 species of Aspidodera showing the digitiform projection of the dextroventral lip "g"; interior, "is"; and exterior sockets, "es." Scale bar = $20 \mu \mathrm{m}$. (a) A. sogandaresi n. sp. male (b) A. fasciata male (c) A. vazi female.
Barroeta 1956 were first described from nine-banded armadillos captured in Guatemala and Mexico, respectively (Caballero, 1955; Flores-Barroeta, 1956). Both species share several similarities with L. trinidadensis, including the shape of the lips, overall structure of the hood, and shape and size of spicules. Nevertheless specimens of $L$. intermedia show a spine between the latero-ventral lips, just at the base of the hood, that serves as the diagnostic character for the species. According to the original description, $L$. dasypi has 3 shields with rectangular shapes in the hood (Flores-Barroeta, 1956). The study of the specimens described by Flores-Barroeta (1956) was not possible because the type specimens and apparently the collection in which they were deposited have since disappeared. Because the dorsal lip of $L$. dasypi is described as being narrower and shorter than the latero-ventral lips, it is not possible that the latter can be rectangular. For these reasons, we consider $L$. dasypi to be a species inquirendae.

The discovery of $A$. vazi, A. binansata, and $L$. trinidadensis in Mexico represents a substantial extension of the known range of these species. While L. trinidadensis now appears to occur in armadillos only around the Caribbean region and in tropical Mexico, both $A$. vazi and $A$. binansata have been collected from armadillos from throughout the subtropical and tropical regions of South and Central America and Mexico. The geographic distribution of both $A$. vazi and A. binansata is nearly concordant with the known range of $D$. novemcinctus (see Taulman and Robbins, 1996). Dasypus novemcinctus has a wide geographic distribution, occurring from northern Argentina to the southcentral United States. This armadillo is capable of surviving in areas with relatively few days of freezing temperatures (Taulman and Robbins, 1996) and has been recently expanding its range to the north. Moreover, some populations of the same species show a continuous range expansion with documented long-distance migration by fertile individuals (Frutos and van den Bussche, 2002).

In a comparable manner, these factors may also explain the presence of $A$. sogandaresi in armadillos over a vast area of Central and North America. Up to the present time, A. sogandaresi appears to be the only sylvatic species of Aspidodera found in the United States. As summarized by Santos et al. (1990), the known host range for A. vazi includes both $D$. novemcinctus and Tolypeutes matacus (Desmarest, 1804), whereas A. binansata has been recorded in D. novemcinctus, Euphractus sexcinctus (Linnaeus, 1758), Cabassous unicinctus (Linnaeus, 1758), Chaetophractus villosus (Desmarest, 1804), and Dasyprocta leporina (Linnaeus, 1758).

\section{ACKNOWLEDGMENTS}

Both work in the field and writing of this paper were supported by National Science Foundation grants BSR-8612329, BSR-9024816, DEB-9496263, DEB-9631295, and DBI-0097019 to S.L.G. We thank Dely Noronha and Luis Muniz (CHIOC), Eric Hoberg (USNPC), Luis García (CNHE), Judith Price (CMN), and Sumiya Ganzorig (CPSVM) for sending us material they have under their care. We thank Ellis Greiner for providing specimens to complete this study and for reviewing an earlier version of the manuscript. Berenit Mendoza and Kit Lee assisted in imaging specimens in SEM. F.A.J.R. is thankful for the support provided by CONACyT-México in the form of a scholarship, and the Walker Graduate Student Funds and the Initiative in Ecology and Evolutionary Ecology, both granted by the School of Biological Sciences of the University of Nebraska, Lincoln. Help in the field was 
generously provided by Sergio Guillén Hernández, Florencia Bertoni, Elizabeth Martínez, Rosario Mata, Ricardo Paredes, and Erick Smith.

\section{LITERATURE CITED}

Albinger, G., A. Fontes, Jr., K. Kerle, N. Link, A. Macy, and S Simon. 1995. SigmaScan Pro. Jandel Scientific Software, San Rafael, California.

Aldes, K. J. 1995. Helminths of the opossum Didelphis virginiana, in southern Illinois, with a compilation of all helminths reported from this host in North America. Journal of the Helminthological Society of Washington 62: 197-208.

CABAllero, E. 1955. Estudios helmintologicos de la región oncocercosa de México y de la república de Guatemala. Nematoda. 9a parte Acta Zoológica Mexicana 1: 1-5.

- AND M. C. Cerecero. 1944. Estudios helmintológicos de la región oncocercosa de México y de la República de Guatemala. Nematoda. Segunda parte. Anales del Instituto de Biología 15: 389-407.

Chandler, A. C. 1932. Notes on the helminths parasites of the opossum (Didelphis virginiana) in southeast Texas, with descriptions of four new species. Proceedings of the United States National Museum 81: $1-15$.

1946. Helminths of armadillos, Dasypus novemcinctus, in Eastern Texas. Journal of Parasitology 32: 237-241.

Flores-Barroeta, L. 1956. Nemátodos de aves y mamíferos I. Acta Zoologica Mexicana 1: 1-9.
Foster, A. O. 1939. Some helminths of the woolly opossum in Panama. Transactions of the American Microscopical Society 58: 185-198.

Frutos, S. D., AND R. A. VAn DEN Bussche. 2002. Genetic diversity and gene flow in nine-banded armadillos in Paraguay. Journal of Mammalogy 83: 815-823.

INGLIS, W. G. 1957. The comparative anatomy and systematic significance of the head in the nematode family Heterakidae. Proceedings of the Zoological Society of London 128: 133-143.

Lamothe-Argumedo, R. L. García-Prieto, D Osorio-Sarabia, AND G. PÉrez-Ponce de León. 1997. Catálogo de la Colección Nacional de Helmintos del I.B.U.N.A.M., 1st Universidad Nacional Autónoma de México, Mexico City, D.F., 211 p.

NAvone, G. T. 1986. Estudios parasitológicos en edentados argentinos. II Nematodes parásitos de armadillos: Aspidodera fasciata (Schneider, 1866); Aspidodera scoleciformis (Diesing, 1851) y Aspidodera vazi Proença, 1937. (Nematoda-Heterakoidea). Neotropica 32: $71-$ 79.

Santos, C. P., H. Lent, And D. C. Gomes. 1990. The genus Aspidodera Railliet and Henry, 1912 (Nematoda: Heterakoidea): Revision, new synonyms and key for species. Revista Brasileira do Biologia 50: 1017-1031.

SoKal, R. R., AND F. J. RohlF. 1995. Biometry: The principles and practice of statistics in biological research, 3rd ed. W. H. Freeman, New York, New York, 887 p.

TAUlman, J. F., AND L. W. RobBins. 1996. Recent range expansion and distributional limits of the nine-banded armadillo (Dasypus novemcinctus) in the United States. Journal of Biogeography 23: 635648. 